\title{
New PLA/ZnO:Cu/Ag bionanocomposites for food packaging
}

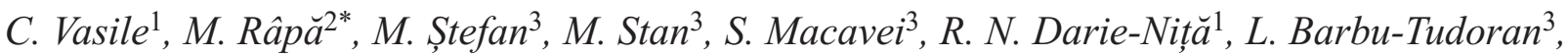

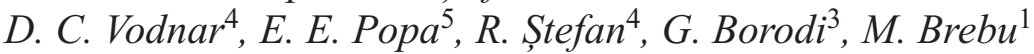

\footnotetext{
1 'Petru Poni' Institute of Macromolecular Chemistry, Physical Chemistry of Polymers Department, 41A Gr. Ghica Voda Alley, 700487 Iasi, Romania

${ }^{2}$ Research Institute of Auxiliary and Organic Producs S.A. ( ICPAO), 8 Carpati St., 551022 Medias, Sibiu, Romania

${ }^{3}$ National Institute for Research and Development of Isotopic and Molecular Technologies INCDTIM, 67-103 Donath St., 400293 Cluj-Napoca, Romania

${ }^{4}$ University of Agronomic Sciences and Veterinary Medicine Cluj-Napoca, Department of Food Science and Technology, 3-5 Manastur Street, 400372 Cluj-Napoca, Romania

${ }^{5}$ University of Agronomic Sciences and Veterinary Medicine Bucharest, Faculty of Biotechnology, 59 Marasti Blv., district 1, 011464 Bucharest, Romania
}

Received 21 November 2016; accepted in revised form 26 January 2017

\begin{abstract}
Plasticized poly(lactic acid) (PLA) samples with embedded $\mathrm{Cu}$-doped $\mathrm{ZnO}$ powder functionalized with Ag nanoparticles composites were prepared by melt blending processing technique. The effect of $\mathrm{ZnO}: \mathrm{Cu} / \mathrm{Ag}$ nanoparticles on the properties of plasticized PLA was investigated in terms of structural (by Attenuated total reflectance - Fourier Transform Infrared - ATR-FT-IR, X-Ray Diffraction analysis - XRD) and morphological (using Scanning Electron Microscopy - SEM and Transmission Electron Microscopy - TEM examination) modifications, thermal (Differential Scanning Calorimetry DSC), mechanical (transmittance, tensile strength), barrier antimicrobial properties and also in respect to migration of $\mathrm{Cu}$, $\mathrm{Zn}$ an $\mathrm{Ag}$ nanoparticles into food simulants. It was found that the increase of nanoparticle content (from 0.5 to $1.5 \mathrm{wt} \%$ ) of PLA formulations leads to the increase of the degree of crystallinity of PLA. The overall migration of all samples into three food simulants was below $10 \mathrm{mg} \cdot \mathrm{dm}^{-2}$, accepted value according to EU Regulation No 10/2011 for plastic materials and articles intended to come into contact with food. Based on the obtained results it can conclude that the optimum composition is $\mathrm{PLA} / \mathrm{ZnO}: \mathrm{Cu} / \mathrm{Ag} \mathrm{0.5}$, this bionanocomposite offering suitable mechanical and thermal properties, good barrier properties to ultraviolet light, water vapour, oxygen and carbon dioxide, antibacterial activity and low migration amount of nanoparticles into food simulants.
\end{abstract}

Keywords: nanocomposites, antibacterial agent, food packaging, material testing

\section{Introduction}

Nowdays, almost all aspects of daily life involve polymeric materials. With increasing environmental awareness around the world, the research and development of biodegradable polymers attracted a great attention [1-3].

Poly(lactic acid) PLA is one of the most popular commercial biodegradable, thermoplastic material being derived from renewable resources. It was studied in combination with other renewable resources, such as cellulose, chitosan $[4,5]$ in particular for food packaging. The general properties required for biodegradable active food packaging materials envisage: antimicrobial function, mecanical, optical and thermal properties, gas barrier and biodegradability [6-8]. The main drawbacks of PLA to be used in food 
packaging are its low gas barrier properties, low processability and its quite slow crystallization rate. Different strategies have been used to improve its barrier properties including barrier surface film coating, multilayer coextrusion, plasma deposition, incorporation of nanoclays, or increasing of crystallization degree $[9,10]$. Regarding the improvement of the PLA processability, many studies have been concerned on the use of bioplasticizers, such as lactic acid oligomers [11], byproducts rich in monoterpens [12], etc. In the case of food packaging, special attention should be addressed to the volatiles and migration of the plasticizers and other compounds into foodstuff [13].

Organic compounds such as chitosan and its derivatives, essential oils, organic acids, enzymes like lysozyme and bacteriocids have been widely studied for their antimicrobial properties and tested for their potential application in polymeric matrices such as antimicrobial packaging. However, such organic compounds present high sensitivity to intense processing conditions (as high temperatures and pressures) necessary in most industrial technologies. The development of microorganisms' resistance also leads to find new solutions for food packaging [14].

Some inorganic compounds at a nanosize scale present strong antibacterial activities at low concentrations due to their high surface area to volume ratio and unique chemical and physical properties. Most antibacterial inorganic materials are metallic nanoparticles and metal oxide nanoparticles such as silver, copper, titanium oxide and zinc oxide, magnesium and calcium oxide, etc. Through the incorporation of metal nanoparticles (NPs) within the polymer matrices versatile materials with interesting properties useful for food packaging applications can be obtained [15]. They are also more stable under extreme conditions such as high temperature and pressures and some of them are considered nontoxic and even contain mineral elements essential to human health.

$\mathrm{ZnO}$ is generally recognized as safe (GRAS) material by the Food and Drug Administration (FDA) and is used as food additive. $\mathrm{ZnO}$ at nanoscale level shows antimicrobial properties and potential applications in food preservation. $\mathrm{ZnO}$ nanoparticles have been incorporated in polymeric matrices in order to provide antimicrobial activity and to improve packaging properties [16]. It was incorporated in polycarbonate and the hydrophobic nanocomposites obtained showed antibacterial, UV-blocking properties [17]. Glass, low density polyethylene (LDPE), polypropylene (PP), polyurethane (PU), paper and chitosan, polyethylene [18] and polypropylene [19] were also coated with $\mathrm{ZnO}$ nanoparticles to obtain antimicrobial food packagings.

Silver is well-known for its wide-range antimicrobial activity against both Gram-positive and Gram-negative bacteria (including antibiotic-resistant strains), fungi and certain viruses. Silver nanoparticles (nanosilver) and copper nanoparticles (nanocopper) exhibit antimicrobial activity and have been incorporated into polymers as polyolefin nanocomposites [20], hydroxypropyl methylcellulose [21] to create antimicrobial packaging materials.

The copper composites are effective against pathogens and bacteria. It can work against viruses and fungi, and other bacteria that cause food poisoning, such as Listeria and Salmonella, and Methicillin resistant Staphylococcus aureus (MRSA), a bacteria that is particularly difficult to treat with antibiotics. Copper nanoparticles embedded in polylactic acid, combining the antibacterial properties of copper nanoparticles with the biodegradability of the polymer matrix [22].

PEG-plasticized PLA-based composite films containing $\mathrm{ZnO}(<50$ and $<100 \mathrm{~nm})$, or $\mathrm{Ag}-\mathrm{Cu}$ alloy were prepared by a solvent casting method [23, 24]. The obtained films show the increased glass transition temperature, thermal stability, crystallinity, much higher tensile strength than that of PLA/PEG blend. The mechanical property drastically reduced with a loading of NPs, which is associated with degradation of PLA. SEM micrographs examination shown that both $\mathrm{Ag}-\mathrm{Cu}$ alloy or $\mathrm{ZnO}$ NPs were dispersed homogeneously in the PLA film matrix.

In case of the materials designed to food packaging application, there are some concerns regarding the migration of $\mathrm{ZnO}, \mathrm{Ag}$ and $\mathrm{Cu}$ nanoparticles to food. Migration of silver ranged from 0.003 to $0.005 \mathrm{mg} / \mathrm{dm}^{2}$, while migration of copper ranged from 0.024 to $0.049 \mathrm{mg} / \mathrm{dm}^{2}$ [20].

Taking into account the antimicrobial activity of $\mathrm{ZnO}, \mathrm{CuO}$ and $\mathrm{Ag}$ nanoparticles it can supposed that their combination will widen the antimicrobial spectrum and also the improvement of some of properties necessary to food packaging will be obtained by using a commonly applied technology as melt processing. The aim of this work was to investigate the influence of $\mathrm{Cu}$-doped $\mathrm{ZnO}$ nanoparticles functionalized with $\mathrm{Ag}$ nanoparticles on the properties of 
plasticized with tributyl $o$-acetyl citrate/Lapol 108 masterbatch PLA polymer intended to obtain new food packaging materials. To our knowledge, the incorporation of nanoparticles (NPs) like $\mathrm{ZnO}: \mathrm{Cu} / \mathrm{Ag}$ alloy as nano-scale fillers into PLA matrix by melt mixing procedure had never been reported before. It was expected that the three-metals $\mathrm{ZnO}$ with bimetallic NPs ( $\mathrm{Cu}$ and $\mathrm{Ag})$ ) containing nanoparticles incorporation into PLA matrix plasticized by melt mixing method confers to the final PLA-based materials good barrier and antibacterial properties as well as low migration of nanoparticles into packaged food.

\section{Experimental part \\ 2.1. Materials}

Polylactic acid (PLA) Ingeo ${ }^{\mathrm{TM}}$ biopolymer 2003D purchased from NatureWorks LLC (Minnetonka, USA), characterized by a residual monomer content of $0.21 \%$, relative viscosity of 3.92 and a $D$-lactide content of $4.5 \%$ was used in this study. It is a thermoplastic resin derived from annually renewable resources and is accepted by the Food \& Drug Administration (FDA) to be used in food packaging.

As bioplasticizers were used: tributyl $o$-acetyl citrate (ATBC) - Proviplast 2624 supplied by Proviron, Belgium (Hemiksem, Belgium) (molecular weight of $406 \mathrm{~g} / \mathrm{mol}$, density at $25^{\circ} \mathrm{C}$ of $1.055 \mathrm{~kg} / \mathrm{l}$ and assay (GC) 99.35\%) and Lapol 108 masterbatch (MB) (as 30\% Lapol 108 in PLA) purchased from Lapol, LLC (Santa Barbara, USA).

Zinc nitrate hexahydrate $-\mathrm{Zn}\left(\mathrm{NO}_{3}\right)_{2} \cdot 6 \mathrm{H}_{2} \mathrm{O}(98 \%$ Sigma Aldrich, St. Louis, Missouri; USA), copper nitrate trihydrate $-\mathrm{Cu}\left(\mathrm{NO}_{3}\right)_{2} \cdot 3 \mathrm{H}_{2} \mathrm{O}(99.5 \%$, Merck, Darmstadt, Germany), oxalic acid dehydrate $\mathrm{H}_{2} \mathrm{C}_{2} \mathrm{O}_{4} \cdot 2 \mathrm{H}_{2} \mathrm{O}$ (Anala ${ }^{\mathrm{TM}}$ Normapur, VWR, Prolabo), silver nitrate $-\mathrm{AgNO}_{3}$ (Sigma Aldrich, St. Louis, Missouri, USA), absolute ethanol (S.C. Nordic S.R.L., Romania) and aqueous solution of Aloe vera leaf extract obtained in our own laboratory were used to obtain $\mathrm{ZnO}: \mathrm{Cu} / \mathrm{Ag}$ nanoparticles.

\subsection{Synthesis of $\mathrm{Cu}$-doped $\mathrm{ZnO}$ nanoparticles}

The copper-doped zinc oxide powders, $\mathrm{Zn}_{1-\mathrm{x}} \mathrm{Cu}_{\mathrm{x}} \mathrm{O}$ $(\mathrm{x}=0.01)$, were synthesized by co-precipitation using a modified version of the experimental procedure reported by Brihi et al. [25]. For this purpose, an oxalate precursor was obtained by co-precipitation of a $0.4 \mathrm{~mol} \cdot \mathrm{L}^{-1}$ aqueous solution of zinc and copper nitrates $\left[\mathrm{Zn}\left(\mathrm{NO}_{3}\right)_{2} \cdot 6 \mathrm{H}_{2} \mathrm{O}\right.$ and $\left.\mathrm{Cu}\left(\mathrm{NO}_{3}\right)_{2} \cdot 3 \mathrm{H}_{2} \mathrm{O}\right]$, respectively, with the same volume of a $0.4 \mathrm{~mol} \cdot \mathrm{L}^{-1}$ solution of oxalic acid $\left(\mathrm{H}_{2} \mathrm{C}_{2} \mathrm{O}_{4} \cdot 2 \mathrm{H}_{2} \mathrm{O}\right)$. The reaction mixture was stirred for $1 \mathrm{~h}$ at room temperature. The light blue precipitate was thoroughly washed with ultrapure water and dried at room temperature. After drying, it was grounded to give fine powder and annealed at $450^{\circ} \mathrm{C}$ (heating rate of $5^{\circ} \mathrm{C} / \mathrm{min}$ ) for $2 \mathrm{~h}$ in air.

\subsection{Functionalization of $\mathrm{Cu}$-doped $\mathrm{ZnO}$ powder with Ag nanoparticles}

The aloe leaf extract mediated green synthesis of silver nanoparticles was applied. The leaf extract of Aloe vera was prepared according to the following procedure: $20 \mathrm{~g}$ of fresh leaves were finely sliced and extracted in $100 \mathrm{~mL}$ ultrapure water at $60-80^{\circ} \mathrm{C}$ with magnetic stirring at $900 \mathrm{rpm}$ for $20 \mathrm{~min}$. The extract was cooled down to room temperature and filtered, then its volume was adjusted to $100 \mathrm{~mL}$ by washing the vegetal residue with ultrapure water, and was further used for functionalization of the nanopowders. Functionalization of $\mathrm{Cu}$-doped $\mathrm{ZnO}$ powder with AgNPs was performed following the procedure reported by Vivekanandhan et al. [26]. For this purpose, the $\mathrm{Cu}$-doped $\mathrm{ZnO}$ powder $(2 \mathrm{~g})$ was dispersed in $500 \mathrm{~mL}$ of $2 \cdot 10^{-3} \mathrm{M} \mathrm{AgNO}_{3}$ solution. The obtained dispersion was sonicated for $2 \mathrm{~h}$, and then $25 \mathrm{~mL}$ of Aloe vera leaf extract was added under continuous stirring with a rate of $500 \mathrm{rpm}$ at room temperature. A change in the reaction mixture colour into brown was observed after $30 \mathrm{~min}$, indicating the formation of silver nanoparticles. The stirring was continued for $24 \mathrm{~h}$ in order to complete the reduction reaction. The $\mathrm{Cu}$-doped $\mathrm{ZnO}$ functionalized with $\mathrm{Ag}$ nanoparticles ( $\mathrm{ZnO}: \mathrm{Cu} / \mathrm{Ag} \mathrm{NPs}$ ) obtained were collected through centrifugation ( $\left.7000 \mathrm{rpm}, 15 \mathrm{~min}, 21^{\circ} \mathrm{C}\right)$. Finally, they were washed several times with absolute ethanol to eliminate the bioresidues and dried at room temperature prior to characterization.

The $\mathrm{ZnO}: \mathrm{Cu} / \mathrm{Ag}$ nanoparticles morphology was examinated by SEM/TEM analysis (see below Figure 3j) and was found a mean size of $\mathrm{ZnO}: \mathrm{Cu} / \mathrm{Ag}$ NPs ranging from $\sim 15-24 \mathrm{~nm}$ (Figure 1).

In all characterizations, the functionalized $\mathrm{Cu}$-doped $\mathrm{ZnO}$ powder with $\mathrm{Ag}$ nanoparticles was coded as $\mathrm{ZnO}: \mathrm{Cu} / \mathrm{Ag}$.

\subsection{Preparation of PLA bionanocomposites}

The ATBC/MB plasticized PLA/ZnO:Cu/Ag bionanocomposites containing $0,0.5,1$ and $1.5 \mathrm{wt} \% \mathrm{Cu}-$ doped $\mathrm{ZnO}$ powder functionalized with $\mathrm{Ag}$ nanoparticles were prepared by melt blending on a Brabender 


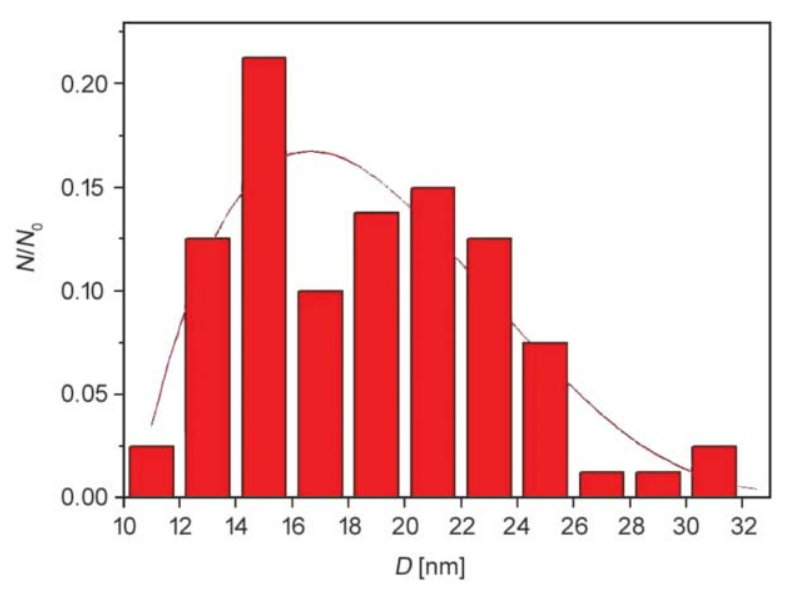

Figure 1. The particle size distribution of $\mathrm{ZnO}: \mathrm{Cu} / \mathrm{Ag}$ nanoparticles evaluated by TEM analysis. N/No number of particles with certain dimension/total number of particles

Plastograph (Duisburg, Germany) at a temperature of $170^{\circ} \mathrm{C}$ and $60 \mathrm{rpm}$. The samples codes as well as their composition are given in Table 1 . The ratios between PLA and plasticizers and MB and ATBC were kept constant at 80:20 and 3:1 (wt\%), respectively. Square sheets with $(150 \times 150 \times 1) \mathrm{mm}$ dimensions and films with thickness below $200 \mu \mathrm{m}$ were prepared from the melted blends by pressing at a temperature of $175^{\circ} \mathrm{C}$, preheating time of $4 \mathrm{~min}$, pressing time of $2 \mathrm{~min}$, under a pressure of $150 \mathrm{~Pa}$ and $125 \mathrm{~Pa}$ respectively, for films and sheets (thickness of $1 \mathrm{~mm}$ ), followed by a sudden cooling of the mold under pressure. The specimens for characterization were taken out from these sheets and films. Neat

Table 1. Studied samples and composition of PLA bionanocomposites

\begin{tabular}{|c|l|c|c|c|}
\hline $\begin{array}{c}\text { No } \\
\text { Crt }\end{array}$ & \multicolumn{1}{|c|}{ Sample Code } & $\begin{array}{c}\text { PLA } \\
{[\mathbf{w t \%} \text { ] }}\end{array}$ & $\begin{array}{c}\text { MB+ATBC } \\
{[\mathbf{w t} \% \mathbf{]}}\end{array}$ & $\begin{array}{c}\text { ZnO:Cu/Ag } \\
{[\mathbf{w t} \%]}\end{array}$ \\
\hline 1 & PLA & 100.0 & & \\
\hline 2 & PLA/ZnO:Cu/Ag 0 & 80.0 & 20.0 & \\
\hline 3 & PLA/ZnO:Cu/Ag 0.5 & 79.6 & 19.9 & 0.5 \\
\hline 4 & PLA/ZnO:Cu/Ag 1 & 79.2 & 19.8 & 1.0 \\
\hline 5 & PLA/ZnO:Cu/Ag 1.5 & 78.8 & 19.7 & 1.5 \\
\hline 6 & ZnO:Cu/Ag & & & 100.0 \\
\hline
\end{tabular}

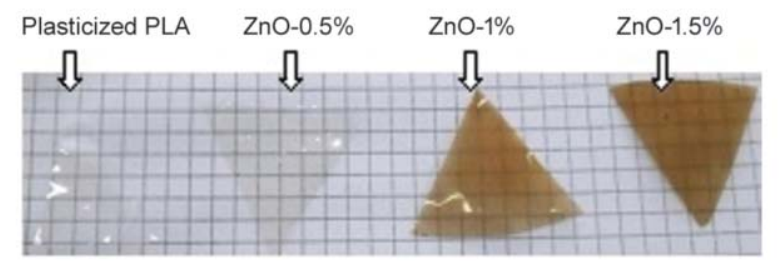

Figure 2. The aspects of PLA/ZnO-Cu/Ag bionanocomposites films with different content of nanoparticles $(0 ; 0.5 ; 1$ and $1.5 \%)$
PLA was used as reference for FT-IR, DSC, barrier and mechanical properties.

The aspects of prepared films of some bionanocomposites in comparison with plasticized PLA are shown in Figure 2.

$\mathrm{By} \mathrm{ZnO}: \mathrm{Cu} / \mathrm{Ag}$ nanoparticles incorporation into plasticized PLA, the brown color is more intense due to the increased AgNPs content. However, all films are transparent, the lines from background being visible (Figure 2).

\subsection{Investigation methods}

\subsubsection{Transmission/scanning electron microscopy (TEM/SEM) and EDX analysis}

The morphology of samples was investigated by transmission/scanning electron microscopy (TEM/SEM) using a Hitachi SU8230 High Resolution Scanning electron Microscope (Tokyo, Japan) equipped with a cold field emission gun. The morphology of the $\mathrm{ZnO}: \mathrm{Cu} / \mathrm{Ag}$ nanoparticles was determined by transmission electron microscopy (TEM). Here, the $\mathrm{ZnO}: \mathrm{Cu} / \mathrm{Ag}$ nanoparticles were dispersed in ethanol, with a BANDELIN SONOREX homogenizer GM 3100 (Berlin, Germany). Fourier analysis of images was made with Digital Micrograph for GMS by Gatan software. For scanning electron microscopy (SEM) analysis the fractured surfaces of composite films was deposited on aluminium stubs and sputtercoated with $10 \mathrm{~nm}$ gold on a Q150T ES Quorum (Oxford, UK).

Elemental composition of the samples was determined by energy dispersive X-ray analysis (EDX), with an EDX-system (X-Max N80TLE Silicon Drift Detector (SDD)) from Oxford Instruments (Oxford, UK). Due to the high voltage of electron beam the samples were melted, complicating the surface analysis.

\subsubsection{Attenuated total reflectance Fourier Transform (ATR-FTIR) spectroscopy}

PLA/ZnO: $\mathrm{Cu} / \mathrm{Ag}$ bionanocomposites films were analyzed in Attenuated Total Reflectance mode Fourier Transform infrared spectroscopy (ATR-FTIR) by using a FTLA 2000-104 spectrophotometer (ABB, Bomem Inc, Québec, Canada) equipped with a $\mathrm{ZnSe}$ crystal with an incidence angle of $45^{\circ}$. All spectra represent the average of 20 scans recorded at $4 \mathrm{~cm}^{-1}$ resolution in a 2000 to $750 \mathrm{~cm}^{-1}$ range, using air as background. The average FTIR spectra of the three measurements of the PLA/ZnO: $\mathrm{Cu} / \mathrm{Ag}$ biocomposite films were normalised to a reference band at the 
wave number of $2945 \mathrm{~cm}^{-1}$ of plasticized PLA. The processing of spectra was achieved by using the SpecView program.

\subsubsection{Differential scanning calorimetry measurements (DSC)}

Thermal analysis of PLA/ZnO:Cu/Ag bionanocomposites was performed using a DSC $823^{\mathrm{e}}$ from Mettler Toledo (Greifensee, Swizerland) calibrated with indium. The weighed samples between 6 and $9 \mathrm{mg}$ were packed in aluminum pans and placed in the DSC cell. The samples were first heated from $30^{\circ} \mathrm{C}$ to $190^{\circ} \mathrm{C}$, kept $2 \mathrm{~min}$ for remove of thermal history, cooled to $30^{\circ} \mathrm{C}$ and reaheated to $190^{\circ} \mathrm{C}$. A heating rate of $5^{\circ} \mathrm{C} \cdot \mathrm{min}^{-1}$ was used for all processes. From DSC curves, second run, the melting temperature $\left[T_{\mathrm{m}}\right]$, enthalpy of melting $\left[\Delta H_{\mathrm{m}}\right]$, cold crystallization temperature and $\left[T_{\mathrm{cc}}\right]$ and its enthalpy and degree of crystallinity $\left[\chi_{c}\right]$ were estimated from all samples.

The degree of crystallinity $\left[\chi_{c}\right]$ of the PLA samples was evaluated by dividing the melting enthalpy of the sample, $\Delta H_{\mathrm{m}}[\mathrm{J} / \mathrm{g}]$ to the enthalpy value for a theoretically $100 \%$ crystalline PLA $\left(\Delta H_{\mathrm{m}}^{0}=93 \mathrm{~J} / \mathrm{g}\right.$ [27]). The weight fraction of PLA from each sample was used for $\chi_{\mathrm{c}}$ calculation.

\subsection{4. $\mathrm{X}$-ray diffraction analysis (XRD)}

Structural characterization and crystalinity degree of polymer samples embedded with nanoparticles were investigated by using a D8 Advance X-ray powder diffractometer (Brucker, Germany), equipped with $\mathrm{Ge}(111)$ in the incident beam, a fast LynxEye detector and a $\mathrm{Cu}-\mathrm{K} \alpha 1$ radiation source $(\lambda=1.54060 \AA)$, operating at $40 \mathrm{kV}$ and $40 \mathrm{~mA}$, as the applied voltage and intensity, respectively, over the incidence angle $(2 \theta)$ in the range of $3-85^{\circ}$, at ambient temperature.

\subsubsection{Transmittance by UV/VIS}

Each film specimen was cut into a rectangular shape and placed directly in a UV/VIS HELIOS ALPHA Spectrophotometer (Thermo Spectronic, Cambridge, $\mathrm{UK}$ ) at the wavelength from 325 to $800 \mathrm{~nm}$. Measurements were performed using air as reference. The results have been expressed as percentage transmittance. The measurements were done in triplicate and the average of three spectra was calculated.

\subsubsection{Tensile properties}

The tensile strength at break, elongation at break and Young modulus were carried out on an Instron 3345
(USA) test machine with a load cell of $1 \mathrm{kN}$ according to the ISO 527. At least five rectangular $(40 \times 4 \times 1) \mathrm{mm}$ test specimens were tested for each composition, at a crosshead speed of $10 \mathrm{~mm} \cdot \mathrm{min}^{-1}$ and the average value was reported.

\subsubsection{Barrier properties \\ Water vapor permeability}

Water vapor transmittance rate (WVTR) of the samples was determined with PBI-Dansensor L 80-5000 (Ringsted, Denmark). The permeability of the samples was performed at $23^{\circ} \mathrm{C}$. Three determinations were made for each sample and the average value was reported.

\section{Gas permeability test}

The gas transmittance rate (of $\mathrm{CO}_{2}$ and $\mathrm{O}_{2}$ ) was conducted with a Lyssy L100-5000 (Systech Instruments Ltd, Illinois, UK) manometric gas permeability tester ( $\sim 4 \mathrm{~h}$ to equilibrium for $\mathrm{CO}_{2}$ and $\sim 7 \mathrm{~h}$ to equilibrium for $\left.\mathrm{O}_{2}\right)$. Specimens with $(108 \times 108 \times 0.2) \mathrm{mm}$ dimensions were used. Four determinations were made for each sample and the average value was reported.

\subsubsection{Migration of metals from composites formulations into simulant media}

Metals release from composites formulations was performed by immersing into different simulant media a fractured surface with $(40 \times 40 \times 1) \mathrm{mm}$ dimensions from all PLA-based biocomposites into $100 \mathrm{ml}$ simulant at $70^{\circ} \mathrm{C}$, for $2 \mathrm{~h}$. Three types of simulant media were tested as follows: distilled water (simulant A), ethanol $10 \%(\mathrm{v} / \mathrm{v})$ in aqueous solution (simulant B) and acetic acid 3\% (w/v) in aqueous solution (simulant $\mathrm{C}$ ). The concentrations of released $\mathrm{Zn}^{2+}, \mathrm{Cu}^{2+}$ and $\mathrm{Ag}^{1+}$ in these simulants were determined by using an inductively coupled plasma atomic emission spectrometer (ICP-AES) (Perkin Elmer 5300 DV, Norwalk, CT, USA). Here, standard solutions with a concentration of $1000 \mathrm{mg} \cdot \mathrm{L}^{-1}$ of $\mathrm{Zn}, \mathrm{Cu}$ and $\mathrm{Ag}$ ions were used for calibration.

\subsubsection{Antibacterial activity}

The bacterial adherence was tested to simulate the affinity of microorganisms to the material surface of $4 \mathrm{~cm}^{2}$. A protocol adapted from previous work [28] was applied for Staphylococcus aureus ATCC 49444 and Pseudomonas aeruginosa ATCC 27853 microorganisms. The bacteria were precultured from a frozen glycerol preparation and inoculated in $45 \mathrm{~mL}$ brain 
heart infusion medium (BHI; BactoTM Brain Heart Infusion, Becton, Dickinson \& Company, Le Pont de Claix, France) for $16 \mathrm{~h}$ at $37^{\circ} \mathrm{C}$. After harvesting the bacteria by centrifugation $\left(4000 \mathrm{rpm},+4^{\circ} \mathrm{C}, 10 \mathrm{~min}\right.$, Centrifuge 5810R, Eppendorf, Hamburg, Germany), they were washed once with phosphate-buffered saline (PBS) (diluted from Dulbecco's Phosphate-Buffered Saline (D-PBS) 10×, Invitrogen, Carlsbad, CA, USA). Then the cells were resuspended in PBS at a concentration of $\sim 0.35$ at $\lambda=550 \mathrm{~nm}$, which corresponded to $\sim 1 \cdot 10^{7}$ colony-forming units (CFU) (measured with a Spectrophotometer BioSpec-mini DNA/RNA/ protein analyzer, Shimadzu Biotech, Kyoto, Japan). The suspension was gently sonicated and vortexed to homogenize the solution. Then, the specimens were placed in test tubes (BD Falcon, $14 \mathrm{~mL}$, Ref 352001, USA) with $5 \mathrm{~mL}$ of bacterial suspension. After rolling (Coulter mixer, Coulter electronics limited, Luton Bedfordshire, UK) at room temperature for $30 \mathrm{~min}$, the specimens were washed three times in abundant physiological saline and gently dried without touching the surface. Thereafter, the bacterial samples from the specimen surfaces were collected for the viability analysis (three replicates). The bacteria attached to the surface of the specimens were collected with micro brushes into microtubes $(2 \mathrm{~mL}$, Sarstedt, Numbrecht, Germany) containing $900 \mu \mathrm{L}$ of Tryptic Soy Broth (TSB, BactoTM Tryptic Soy Broth, Becton, Dickinson \& Company, Wilson, NC, USA) with 10\% glycerol. Thereafter, the bacteria were sonicated $(\sim 5 \mathrm{~s}$ with a tipsonicator type UP $50 \mathrm{H}$ Ultrasonic Processor, Hielscher, Teltow, Germany cycle 1, amplitude $100 \%$ ), serially diluted in physiological saline solution $(10 \mu \mathrm{L}$ of $1: 10,1: 100$, and 1:1000) and cultured on blood agar plates. CFU measurements were done after $16 \mathrm{~h}$ of culturing at $37^{\circ} \mathrm{C}$.

\section{Results and discussions}

\subsection{SEM analysis}

The morphology of the films samples containing PLA, plasticizers and $\mathrm{ZnO}: \mathrm{Cu} / \mathrm{Ag}$ nanoparticles and $\mathrm{ZnO}: \mathrm{Cu} / \mathrm{Ag}$ nanoparticles was investigated using scanning electron microscopy - Figure 3 . The plasticized PLA (Figure 3a) shows a smooth surface with very small pores of almost spherical shape, evidenced at high magnification (Figure $3 b$ ). The SEM images of biocomposite containing $0.5 \mathrm{wt} \% \mathrm{ZnO}: \mathrm{Cu} /$ $\mathrm{Ag}$ nanoparticles reveal the presence of spherical aggregates of about $50-100 \mathrm{~nm}$, relatively uniform distributed on surface of polymer film (Figure 3c).
It can be noticed that aggregations tend to locate in pores of PLA matrix having a homogeneous dispersion in PLA matrix (Figure 3d). With the increase of the nanoparticles content (for 1 and $1.5 \mathrm{wt} \%$ ) the tendency to aggregation is much pronounced and the distribution of $\mathrm{ZnO}: \mathrm{Cu} / \mathrm{Ag}$ nanoparticles is not more homogeneous (Figures 3e-3h).

The change in morphology is associated with the effect the $\mathrm{ZnO}: \mathrm{Cu} / \mathrm{Ag}$ nanoparticles. It is obvious that the incorporation of $\mathrm{ZnO}: \mathrm{Cu} / \mathrm{Ag}$ nanoparticles in PLA matrix promotes the reorganization of the matrix, in concordance with the DSC/XRD results reported in Table 3 and Table 4. The spatial homogeneous dispersion of elements and of the $\mathrm{ZnO}: \mathrm{Cu}-\mathrm{Ag}$ nanoparticles in PLA matrix and the quantitative composition of the film were confirmed by EDX analysis (Figures 4 and 5) and Table 2.

EDX spectra and maping images allow highlighting the presence of $\mathrm{Zn}, \mathrm{O}, \mathrm{Cu}, \mathrm{Ag}$ along with $\mathrm{C}$ from polymer matrix.

As concerns the surface composition of the PLA/ $\mathrm{ZnO}: \mathrm{Cu} / \mathrm{Ag} 1.5$ film it is seems that low amount of $\mathrm{AgNPs}$ is located on surface, while $\mathrm{Zn}$ and $\mathrm{Cu}$ are in a higher concentration.

\subsection{ATR-FTIR spectroscopy characterization}

Normalizated ATR-FTIR spectra of the neat PLA, plasticized PLA and the PLA/ZnO:Cu/Ag biocomposite films are presented in Figure 6.

The bands in the ATR-FTIR spectra of PLA bionanocomposites assigned according to the literature data [29] are placed at following wave numbers: $1454 \mathrm{~cm}^{-1}$ (C-H stretching of $-\mathrm{CH}_{3}$; asymmetric deformation), 1383 and $1360 \mathrm{~cm}^{-1}$ (C-H stretching of $\mathrm{CH}_{3}$; symmetric deformation), 1267, 1180, 1128, 1082 and $1041 \mathrm{~cm}^{-1}(-\mathrm{C}-\mathrm{O}-$ stretching vibration in $-\mathrm{O}-\mathrm{C}=\mathrm{O})$ and $868 \mathrm{~cm}^{-1}$ (C-O-C stretching). The band centered at $1749 \mathrm{~cm}^{-1}$ is assigned to the $\mathrm{C}=\mathrm{O}$ stretching of the ester group of PLA. The weak bands around 2944 and $2995 \mathrm{~cm}^{-1}$ (not shown) are assigned to the $\mathrm{C}-\mathrm{H}$ stretching of $\mathrm{CH}_{3}$.

Table 2. Elemental composition of the PLA/ZnO:Cu/Ag 1.5 film

\begin{tabular}{|c|r|}
\hline Element & [wt\%] \\
\hline $\mathrm{C}$ & 53.76 \\
\hline $\mathrm{O}$ & 45.34 \\
\hline $\mathrm{Cu}$ & 0.15 \\
\hline $\mathrm{Zn}$ & 0.74 \\
\hline $\mathrm{Ag}$ & 0.01 \\
\hline Total & 100.00 \\
\hline
\end{tabular}



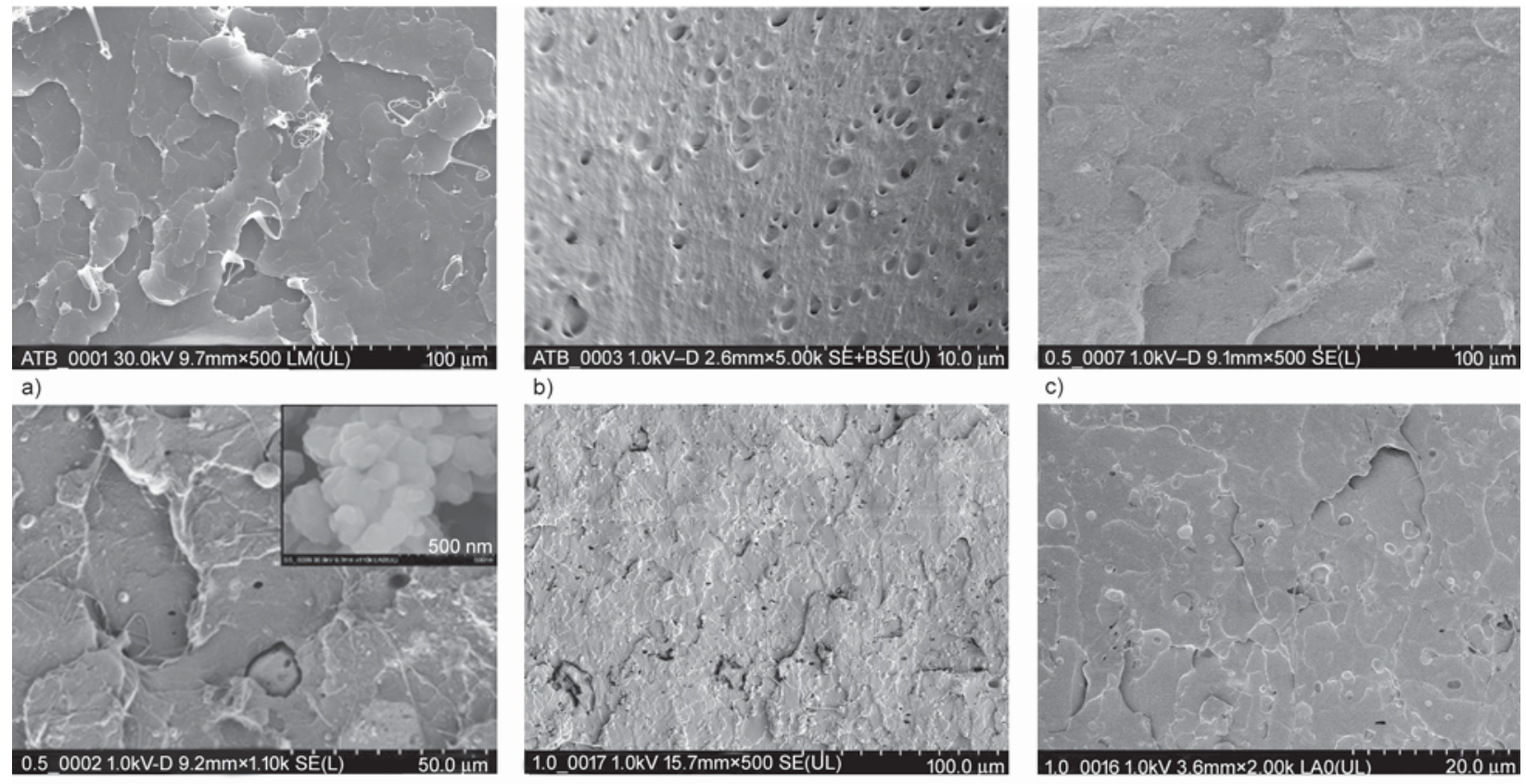
b)

d)
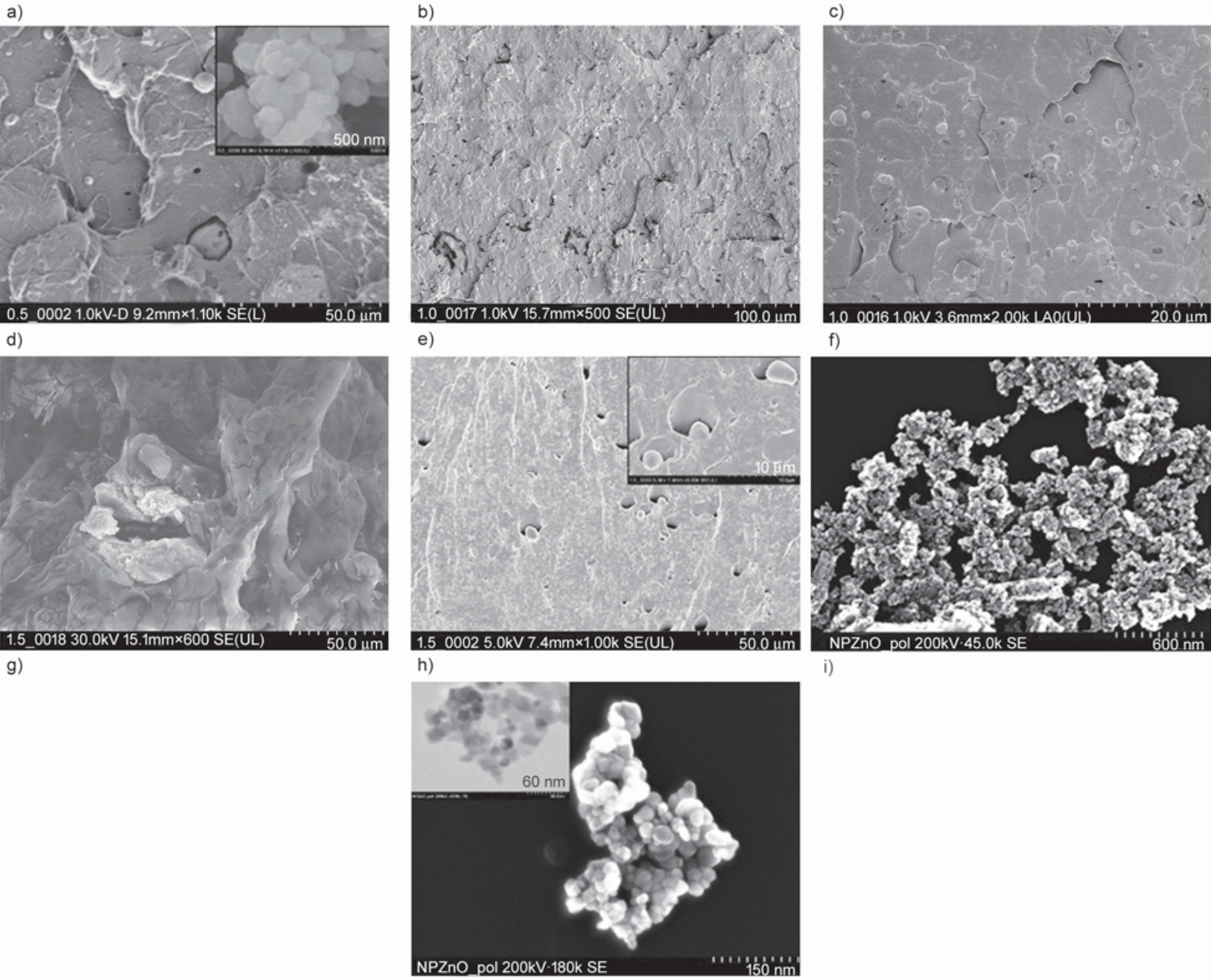

j)

Figure 3. SEM micrographs of the fractured surface of the PLA-plasticizer and PLA nanocomposites: a-b) Plasticized PLA; c-d) PLA/ZnO:Cu/Ag 0.5; e-f) PLA/ ZnO:Cu/Ag 1; g-h) PLA/ZnO:Cu/Ag 1.5; i-j) TEM micrographs of the $\mathrm{ZnO}: \mathrm{Cu} / \mathrm{Ag} \mathrm{NPs}$

A significant decrease in the intensity of bands was observed for PLA-bionanocomposites films containing 1 and $1.5 \% \mathrm{Zno}: \mathrm{Cu} / \mathrm{Ag}$ NPs in respect with those of the plasticized PLA mainly for those with maximum at: $868,895 \mathrm{~cm}^{-1}$ (corresponding to the coupling of $\mathrm{C}-\mathrm{C}$ backbone stretching with the crystalline $\mathrm{C}-\mathrm{O}-\mathrm{C}$ vibration bands), $957 \mathrm{~cm}^{-1}(\mathrm{O}-\mathrm{H}$ vibration of carboxylic acid), $1267 \mathrm{~cm}^{-1}$ (C-O-C stretching), 1360,1383 and $1749 \mathrm{~cm}^{-1}$.

With respect to plasticized PLA film, the increased intensity of bands was observed for $\mathrm{ZnO}: \mathrm{Cu} / \mathrm{Ag} 0.5 \%$

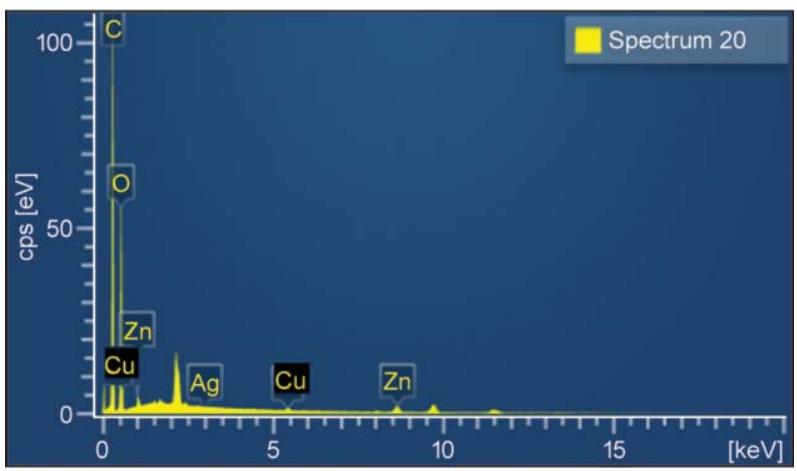

Figure 4. EDX image of PLA/ZnO:Cu/Ag 1.5 film 


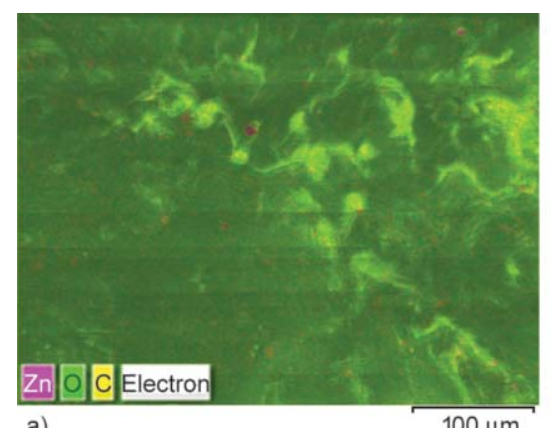

a)

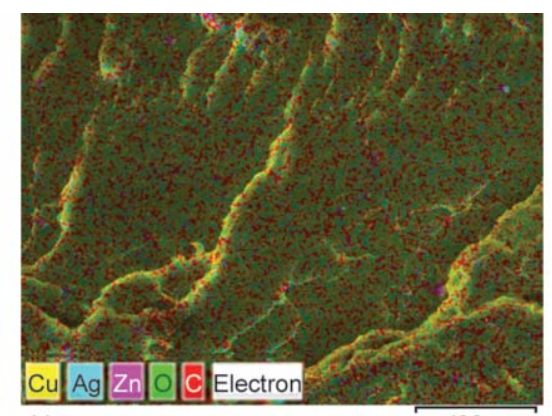

$100 \mu \mathrm{m}$

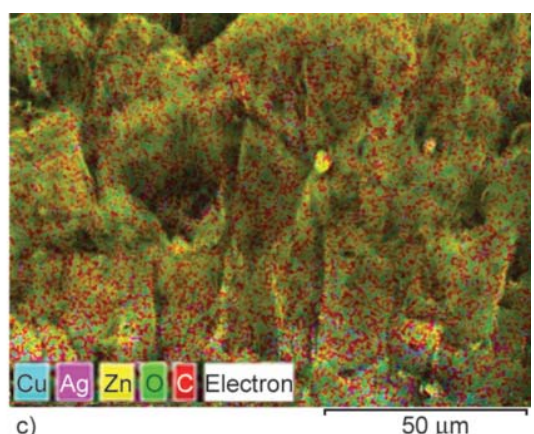

$50 \mu \mathrm{m}$

Figure 5. Distribution of elements in PLA loading with different percentage of $\mathrm{ZnO}: \mathrm{Cu} / \mathrm{Ag}$ nanoparticles. a) PLA/ZnO:Cu/Ag 0.5 ; b) PLA/ZnO:Cu/Ag 1 ; c) PLA/ZnO:Cu/Ag 1.5

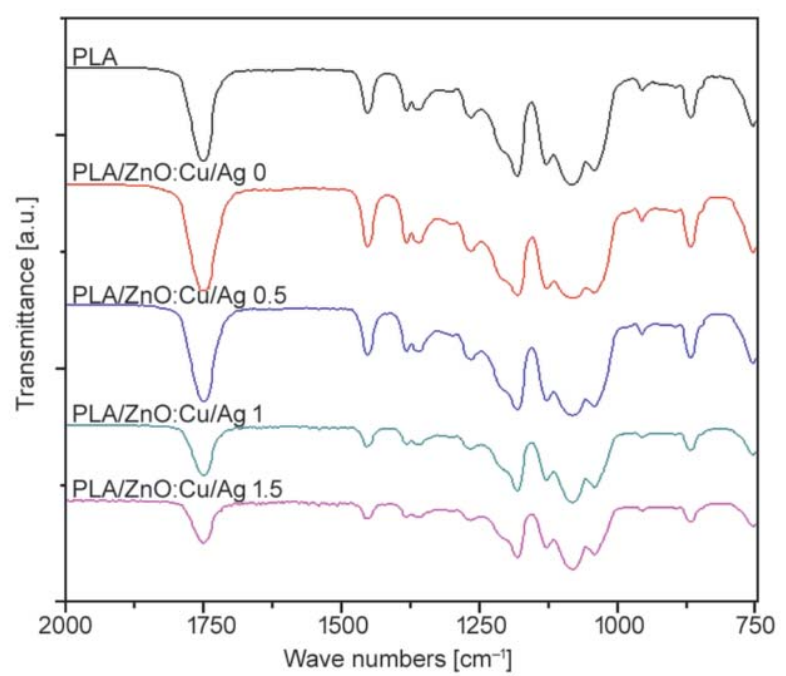

Figure 6. Normalized FTIR spectra of PLA bionanocomposites in comparison with plasticized PLA and neat PLA in the wave numbers range of $2000-750 \mathrm{~cm}^{-1}$. All spectra were recorded on films with thickness below $100 \mu \mathrm{m}$.

at 895 and at $957 \mathrm{~cm}^{-1}$ which signifies the formation of strong inter-component interactions and a good dispersion of nanoparticles and also that some changes in the polymer chain arrangements occured [30].

At the same time, the band at $1454 \mathrm{~cm}^{-1}$ decreased by $18 \%$ for $\mathrm{PLA} / \mathrm{ZnO}: \mathrm{Cu} / \mathrm{Ag} 0.5 \%$ film, by $65 \%$ for PLA/ZnO: $\mathrm{Cu} / \mathrm{Ag} 1 \%$ film and by $72 \%$ in the case of PLA/ZnO: $\mathrm{Cu} / \mathrm{Ag} 1.5 \%$, respectively, in comparison with plasticized PLA film. Also, the incorporation of $\mathrm{ZnO}: \mathrm{Cu} / \mathrm{Ag}$ NPs leads to the decrease of the absorption band at $868 \mathrm{~cm}^{-1}$ by $57 \%$ for $\mathrm{ZnO}: \mathrm{Cu} / \mathrm{Ag} 1 \%$, and by $167 \%$ for $\mathrm{ZnO}: \mathrm{Cu} / \mathrm{Ag} 1.5 \%$ as compared to that of the plasticized PLA. The same spectral behavior, i.e. the increase the maximum intensity of the bands at 1267,1360 and $1383 \mathrm{~cm}^{-1}$ (C-O ester stretch and $\delta \mathrm{CH}$ ) for $\mathrm{ZnO}: \mathrm{Cu} / \mathrm{Ag} 0.5 \%$ but the decrease of their intensity by the incorporation of higher amount of nanoparticles namely for $\mathrm{ZnO}: \mathrm{Cu} / \mathrm{Ag} 1 \%$ and $\mathrm{ZnO}: \mathrm{Cu} / \mathrm{Ag} 1.5 \%$ was observed. This could be ex- plained by changes in crystalinity by nanoparticles incorporation.

\subsection{Differential scanning calorimetry (DSC)}

It is well-known that PLA under practical processing conditions shows a low crystallinity or it is an amorphous form due to the intrinsic slow crystallization rate, which limits its applications in the automotive and packaging fields. The synergistic effect of plasticizers and nucleating agents in the crystallinity increase was found by the study of the thermal and mechanical properties of PLA nanocomposites [31], in which crystallization by heating (cold crystallization takes place) and crystallinity degree could vary from $12 \%$ to more than $30 \%[5,32]$ depending on processing and heating conditions, plasticizer and nucleating agent type and concentration. From the DSC curves of the neat PLA and PLA/ZnO: $\mathrm{Cu} / \mathrm{Ag}$ bionanocomposites - Figure 7, the thermal characteristics have been determined and they are given in Table 3. The DSC curves of samples displayed a glass transition temperature, a well visible exothermal cold

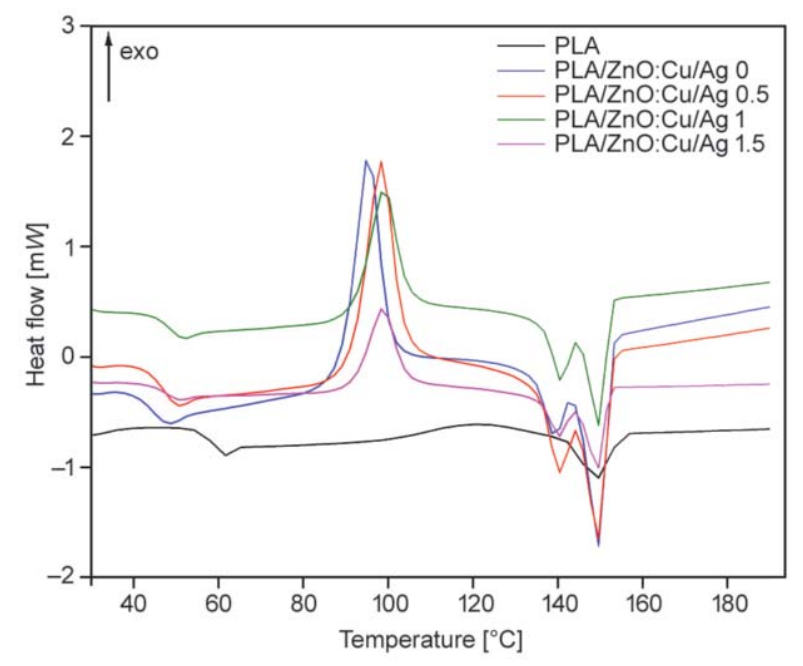

Figure 7. DSC curves for the neat PLA and its biocomposites with $\mathrm{ZnO}: \mathrm{Cu} / \mathrm{Ag}$ NPs (the second run) 
Table 3. Some thermal properties of PLA and PLA bionanocomposites

\begin{tabular}{|l|c|c|c|c|c|c|}
\hline \multicolumn{1}{|c|}{ Sample } & $\begin{array}{c}\boldsymbol{T}_{\mathbf{g}} \\
{\left[{ }^{\circ} \mathbf{C}\right]}\end{array}$ & $\begin{array}{c}\Delta \boldsymbol{H}_{\mathbf{c c}} \\
{[\mathbf{J} / \mathbf{g}]}\end{array}$ & $\begin{array}{c}\boldsymbol{T}_{\mathbf{c c}} \\
{\left[{ }^{\circ} \mathbf{C}\right]}\end{array}$ & $\begin{array}{c}\Delta \boldsymbol{H}_{\mathbf{m}} \\
{[\mathbf{J} / \mathbf{g}]}\end{array}$ & $\begin{array}{c}\boldsymbol{T}_{\mathbf{m}} \\
{\left[{ }^{\circ} \mathbf{C}\right]}\end{array}$ & $\begin{array}{c}\chi_{\mathbf{c}} \text { PLA } \\
{[\mathbf{\%}]}\end{array}$ \\
\hline Neat PLA & 57.5 & 8.3 & 119.2 & 9.4 & 148.7 & 10.1 \\
\hline PLA/ZnO:Cu/Ag 0 & 44.0 & 20.0 & 95.4 & 22.9 & $\begin{array}{c}149.8 ; \\
139.2\end{array}$ & 30.8 \\
\hline PLA/ ZnO:Cu/Ag 0.5 & 46.4 & 21.7 & 98.3 & 23.1 & $\begin{array}{l}149.5 ; \\
140.2\end{array}$ & 31.2 \\
\hline PLA/ ZnO:Cu/Ag 1 & 48.5 & 20.7 & 99.1 & 23.4 & $\begin{array}{l}149.7 ; \\
140.7\end{array}$ & 31.8 \\
\hline PLA/ ZnO:Cu/Ag 1.5 & 47.5 & 21.2 & 98.7 & 23.3 & $\begin{array}{l}149.3 ; \\
140.1\end{array}$ & 31.7 \\
\hline
\end{tabular}

crystallization process and the endothermal melting process as a double peak, probably due to different types of crystalites with different lamellar thickness or reorganization during melting - Figure 7 . From DSC curve of neat PLA (Figure 7) is observed a transition at $57.5^{\circ} \mathrm{C}$ that is attributed to the glass transition $\left(T_{\mathrm{g}}\right)$ relaxational process resulting from micro-Brownian motion of the main chain backbone, a cold crystallization peak at $119.2^{\circ} \mathrm{C}$ and a melting peak at $148.7^{\circ} \mathrm{C}$. In comparison with neat PLA, the plasticized blends and bionanocomposites show $T_{\mathrm{g}}$ at lower temperatures. This suggests that the segmental mobility of amorphous pure PLA increases due to the addition of plasticizers [33] and by incorporation of $\mathrm{ZnO}: \mathrm{Cu} / \mathrm{Ag}$ NPs a slight increase in $T_{\mathrm{g}}$ can be noticed in comparison with plasticized PLA (PLA/ZnO:Cu/Ag 0). Plasticized PLA and PLA bionanocomposites exhibit the cold crystallization temperature $\left(T_{\mathrm{cc}}\right)$ at lower values $\left(95.4-99.1^{\circ} \mathrm{C}\right)$ than neat PLA $\left(119.2^{\circ} \mathrm{C}\right)$, these low values of Tcc favor the crystallization process. The increase of $\mathrm{ZnO}: \mathrm{Cu} / \mathrm{Ag}$ NPs content led to shift of Tcc at high temperatures $\left(\sim 99.1^{\circ} \mathrm{C}\right)$ than plasticized PLA $\left(95.4^{\circ} \mathrm{C}\right)$. The increase of $T_{\mathrm{cc}}$ together with increase of $T_{\mathrm{g}}$ was attributed to the inorganic nanoparticles presence within the PLA matrix [34]. The enthalpy of melting, $\Delta H_{\mathrm{m}}$, increased as the amount of $\mathrm{ZnO}: \mathrm{Cu} / \mathrm{Ag}$ NPs increased in comparison with neat and plasticized PLA - Table 3. Both plasticizer system (ATBC/MB) and $\mathrm{ZnO}: \mathrm{Cu} / \mathrm{Ag}$ nanoparticles act as nucleating agent leading to the increase of the crystallinity degree up to $31.8 \%$ with respect to that of the neat PLA and this increase will have an effect on the barrier properties improvements of the PLA bionanocomposites.

\subsection{X-ray diffraction results}

In Figure 8 the diffraction patterns for $\mathrm{ZnO}: \mathrm{Cu} / \mathrm{Ag}$ nanoparticles and polymer composites embedded with
$\mathrm{ZnO}: \mathrm{Cu} / \mathrm{Ag}$ nanoparticles with Miller indices corresponding to the reflexion peaks are presented. For PLA-composites, the diffraction intensities increase with $\mathrm{ZnO}: \mathrm{Cu} / \mathrm{Ag}$ nanoparticles concentrations.

From Figure 8 it can see that the all powder diffraction patterns present a large halo with its maxima at $2 \theta=15.8^{\circ}$ and a small halo at $2 \theta=31.9^{\circ}$. Interplanar spacing, $d$, corresponding to $2 \theta=15.8^{\circ}$ is $5.6 \AA$ and for $2 \theta=31.9^{\circ}$ is $2.8 \AA$. This suggests that the polymer crystalline phase is stratified, the distance between layers being $5.6 \AA$ and the diffraction angles corresponding for the two halos are the order 1 and order 2 of diffraction from Bragg relationship. Two additional diffraction peaks appeared at $38.15^{\circ}$ and $44.3^{\circ}$ corresponding to Ag metallic nanoparticles with cubic structure [35].

The most frequently occurring interatomic distances, $R$, is given by Equation (1) [36]:

$R=1.25 \cdot d_{\mathrm{Bragg}}$

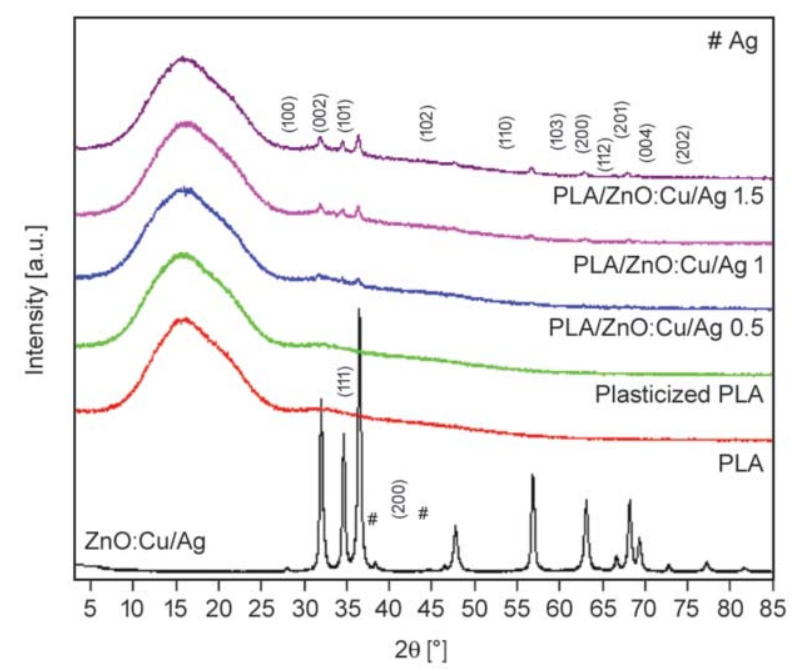

Figure 8. X-ray diffraction pattern of the $\mathrm{ZnO}: \mathrm{Cu} / \mathrm{Ag}$ nanoparticles, neat PLA, plasticized PLA and PLA/ $\mathrm{ZnO}: \mathrm{Cu} / \mathrm{Ag}$ bionanocomposites films 
where $d_{\text {Bragg }}$ is the interplanar spacing corresponding to the large halo is $R=7 \AA$, in agreement with literature data [37].

The degree of crystallinity, $X_{\mathfrak{c}}$, was evaluated as the ratio of the diffraction peaks area and the total diffraction area which includes diffraction peaks and amorphous halo [38]. To assess the degree of crystallinity, the Reflex computer program part of Material Studio software suit was used. The values obtained for $X_{\mathrm{c}}$ are summarized in Table 4.

From the data in Table 4 is observed that the incorporation of $\mathrm{ZnO}: \mathrm{Cu} / \mathrm{Ag}$ NPs into PLA and plasticized PLA led to increase of crystallinity of samples, in good correlation with the decreasing of carbonyl band at $1749 \mathrm{~cm}^{-1}$ reported in FTIR spectra (Figure 6). Using the Scherrer formula, the average crystallite sizes for $\mathrm{ZnO}: \mathrm{Cu}-\mathrm{Ag}$ nanoparticles were calculated on the (101), (002) and (100) peaks. The crystallite dimension is $15 \mathrm{~nm}$, in good agreement with the TEM analysis results.

\subsection{Transmittance in UV/VIS}

One of the desired characteristics of a packaging material is that it must fulfill aesthetic aspect. To determine the light transmission properties of the films, they were scanned at wavelengths ranging from 330 to $800 \mathrm{~nm}$ and the percentage light transmittance was recorded (Figure 9).

Film samples exhibited low light transmission in UV light, especially at wavelength of $330 \mathrm{~nm}$. Higher $\mathrm{ZnO}: \mathrm{Cu} / \mathrm{Ag} \mathrm{NP}$ content of the bionanocomposites lower percetage UV light transmission is, suggesting a good barrier of biocomposites to ultraviolet light,

Table 4. The crystallinity of PLA, plasticized PLA and $\mathrm{PLA} / \mathrm{ZnO}: \mathrm{Cu} / \mathrm{Ag}$ films obtained from XRD analysis

\begin{tabular}{|l|c|}
\hline \multicolumn{1}{|c|}{ Sample code } & $\begin{array}{c}\boldsymbol{X}_{\mathbf{c}} \\
{[\mathbf{\%}]}\end{array}$ \\
\hline PLA & 9.90 \\
\hline PLA/ZnO:Cu/Ag $0 \%$ & 9.94 \\
\hline PLA/ZnO:Cu/Ag 0.5 & 11.05 \\
\hline PLA/ZnO:Cu/Ag 1 & 12.34 \\
\hline PLA/ZnO:Cu/Ag 1.5 & 13.75 \\
\hline
\end{tabular}

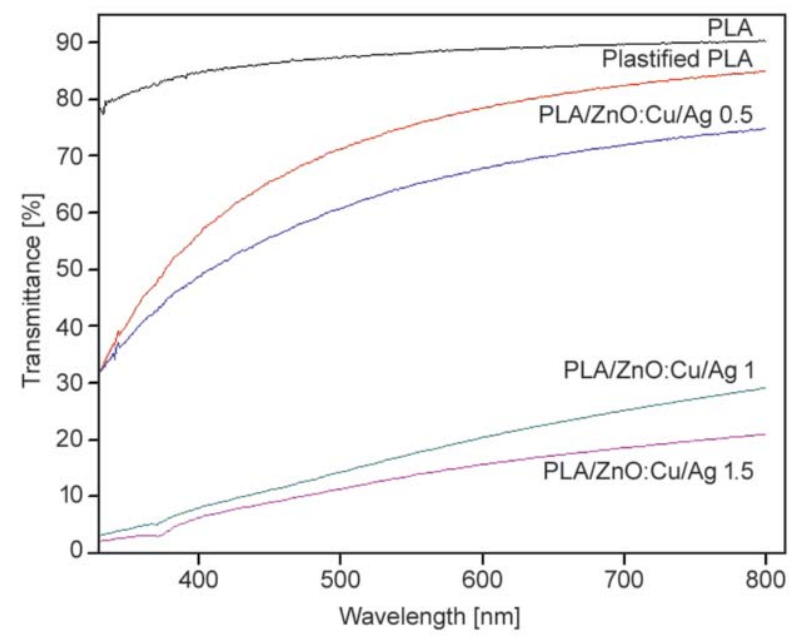

Figure 9. UV light transmission of the PLA, plastified PLA and PLA bionanocomposite films

a powerful lipid-oxidizing agent in food systems. At $375 \mathrm{~nm}$, the PLA/ZnO:Cu/Ag 1\% and PLA/ZnO:Cu/ Ag $1.5 \%$ films show a plasmon resonance characteristic to Ag. In the range of visible spectra, the sample containing $0.5 \% \mathrm{ZnO}: \mathrm{Cu} / \mathrm{Ag}$ NPs shows the transmittance around $75 \%$, whereas, in the case of PLA/ $\mathrm{ZnO}: \mathrm{Cu} / \mathrm{Ag} 1 \%$ and $\mathrm{PLA} / \mathrm{ZnO}: \mathrm{Cu} / \mathrm{Ag} 1.5 \%$ films the transmittance values further reduced. This effect is due to the incorporation and distribution of $\mathrm{ZnO}: \mathrm{Cu} / \mathrm{Ag}$ nanoparticles into plasticized PLA as it was observed in Figure 3e-3h. Therefore it can concluded that the $\mathrm{PLA} / \mathrm{ZnO}: \mathrm{Cu} / \mathrm{Ag} 0.5 \%$ can be used in food packaging materials as a good transparent material.

\subsection{Tensile properties}

The tensile properties of the PLA-based bionanocomposites are summarized in Table 5 .

PLA has a high tensile strength and Young modulus but because of its britleness the elongation at break is very low - Table 5. The addition of plasticizers (MB and ATBC) leads as expected, to an increase of the elongation at break with respect to neat PLA but with a decrease in the tensile strength at break and modulus. The loading of $\mathrm{ZnO}: \mathrm{Cu} / \mathrm{Ag}$ nanoparticles into plasticized PLA has a slowly increased effect of the tensile strength at break with a maximum value of

Table 5. Tensile properties of the neat PLA and PLA/ ZnO:Cu/Ag bionanocomposites

\begin{tabular}{|l|c|c|c|}
\hline \multicolumn{1}{|c|}{ Sample code } & $\begin{array}{c}\text { Tensile strength at break } \\
{[\mathbf{M P a}]}\end{array}$ & $\begin{array}{c}\text { Elongation at break } \\
{[\%]}\end{array}$ & $\begin{array}{c}\text { Young modulus } \\
\text { [MPa] }\end{array}$ \\
\hline Neat PLA & $69.28 \pm 0.18$ & $2.14 \pm 0.10$ & $4048 \pm 17$ \\
\hline PLA/ZnO:Cu/Ag 0 & $44.81 \pm 9.19$ & $3.30 \pm 0.64$ & $2898 \pm 149$ \\
\hline PLA/ ZnO:Cu/Ag 0.5 & $45.32 \pm 7.53$ & $2.78 \pm 0.23$ & $2934 \pm 161$ \\
\hline PLA/ ZnO:Cu/Ag 1 & $48.39 \pm 5.35$ & $2.67 \pm 0.52$ & $3058 \pm 72$ \\
\hline PLA/ ZnO:Cu/Ag 1.5 & $47.28 \pm 2.75$ & $2.61 \pm 0.27$ & $3010 \pm 107$ \\
\hline
\end{tabular}


Table 6. Transmission rate of samples

\begin{tabular}{|l|c|c|c|}
\hline \multicolumn{1}{|c|}{ Sample code } & $\begin{array}{c}\text { Water vapor } \\
{\left[\mathbf{g} \cdot \mathbf{m}^{-\mathbf{2}} \cdot \mathbf{d a y}^{-\mathbf{1}} \mathbf{]}\right.}\end{array}$ & $\begin{array}{c}\mathbf{C O}_{\mathbf{2}} \\
{\left[\mathbf{m L} \cdot \mathbf{m}^{-\mathbf{2}} \cdot \mathbf{d a y}^{-\mathbf{1}} \mathbf{]}\right.}\end{array}$ & $\begin{array}{c}\mathbf{O}_{\mathbf{2}} \\
{\left[\mathbf{m L} \cdot \mathbf{m}^{-\mathbf{2}} \cdot \mathbf{d a y}^{-\mathbf{1}} \mathbf{]}\right.}\end{array}$ \\
\hline Neat PLA & 15.94 & 873 & 1308 \\
\hline PLA/ZnO:Cu/Ag 0 & 13.70 & 260 & 104 \\
\hline PLA/ZnO:Cu/Ag 0.5 & 11.35 & 230 & 97 \\
\hline PLA/ZnO:Cu/Ag 1 & 18.72 & Invalid test & Invalid test \\
\hline PLA/ZnO:Cu/Ag 1.5 & 15.60 & Invalid test & Invalid test \\
\hline
\end{tabular}

48-47 MPa for $\mathrm{ZnO}: \mathrm{Cu} / \mathrm{Ag} 1$ or $1.5 \%$. This is possible be due to a homogeneous distribution of $\mathrm{ZnO}: \mathrm{Cu} /$ $\mathrm{Ag}$ nanoparticles into PLA matrix and the high aspect ratio of nanoparticles that restrict the chain movements. A similar improvement in the mechanical properties of PLA film nanocomposites reinforced with both $\mathrm{Ag}-\mathrm{Cu}$ alloy or $\mathrm{ZnO}$ nanoparticles has been reported $[23,30]$.

\subsection{Barrier properties}

Water vapor transmittance rate (WVTR) and gas permeability transmittance rate of the developed bionanocomposites are shown in Table 6 .

When compared with neat PLA, the incorporation of small amount of $\mathrm{ZnO}: \mathrm{Cu} / \mathrm{Ag} \mathrm{NPs}(0.5 \mathrm{wt} \%)$ into plastified PLA leads to the decrease of the water vapor transmittance rate (WVTR) and gas permeability transmittance rate, therefore the PLA/ZnO:Cu/Ag 0.5 bionanocomposite shows good barrier properties Table 6. For higher amount of $\mathrm{ZnO}: \mathrm{Cu} / \mathrm{Ag}$ NPs the barrier properties decrease or they can not be evaluated because of inhomogeneity of the films. Considering the reported WVTR of $2.43 \mathrm{~g} \cdot \mathrm{m}^{-2}$. day ${ }^{-1}$ and the oxygen transmission rate (OTR) of $2838 \mathrm{~mL} \cdot \mathrm{m}^{-2} \cdot$ day $^{-1}$ for virgin LDPE film [39] and those of neat PLA reported here, we can appreciate that the film with $0.5 \%$ $\mathrm{ZnO}: \mathrm{Cu} / \mathrm{Ag}$ NPs can be considered appropriate for food packaging applications.

\subsection{Migration of metals from composites formulations into simulant media}

Migration of $\mathrm{Zn}, \mathrm{Cu}, \mathrm{Ag}$ ions from PLA based polymeric formulations destined to food packaging into different simulant media was determined by immersing of biocomposite films into three food simulants [13] for $2 \mathrm{~h}$ at $70^{\circ} \mathrm{C}$, as follows: distilled water (simulant $\mathrm{A}$ ), ethanol 10\% (v/v) in aqueous solution (simulant B) and acetic acid 3\% (w/v) in aqueous solution (simulant $\mathrm{C}$ ) - Table 7

The migration of the $\mathrm{Cu}$ and $\mathrm{Zn}$ increased with amount of $\mathrm{ZnO}: \mathrm{Cu} / \mathrm{Ag}$ NPs in PLA matrix for all food simulants - Table 7 . The $\mathrm{Cu}$ ions show a very
Table 7. Metals migration values from bionanocomposites into three food simulants

\begin{tabular}{|c|c|c|c|}
\hline \multirow{2}{*}{ Sample code } & Simulant A & Simulant B & Simulant C \\
\hline & \multicolumn{3}{|c|}{$\mathrm{Zn}\left[\mathrm{mg} \cdot \mathbf{d m}^{-2}\right]$} \\
\hline PLA/ZnO:Cu/Ag 0.5 & 0.248 & 0.684 & 0.613 \\
\hline PLA/ZnO:Cu/Ag 1 & 1.248 & 3.037 & 4.280 \\
\hline \multirow[t]{2}{*}{ PLA/ZnO:Cu/Ag 1.5} & 1.725 & 3.156 & 4.550 \\
\hline & \multicolumn{3}{|c|}{$\mathrm{Cu}\left[\mathrm{mg} \cdot \mathrm{dm}^{-2}\right]$} \\
\hline PLA/ZnO:Cu/Ag 0.5 & 0.005 & 0.005 & 0.040 \\
\hline PLA/ZnO:Cu/Ag 1 & 0.007 & 0.019 & 0.051 \\
\hline \multirow[t]{2}{*}{ PLA/ZnO:Cu/Ag 1.5} & 0.011 & 0.185 & 0.093 \\
\hline & \multicolumn{3}{|c|}{$\operatorname{Ag}\left[\mathbf{m g} \cdot \mathrm{dm}^{-2}\right]$} \\
\hline $\mathrm{PLA} / \mathrm{ZnO}: \mathrm{Cu} / \mathrm{Ag} 0.5$ & 0.001 & 0.001 & 0.001 \\
\hline PLA/ZnO:Cu/Ag 1 & 0.001 & 0.001 & 0.001 \\
\hline PLA/ZnO:Cu/Ag 1.5 & 0.001 & 0.001 & 0.001 \\
\hline
\end{tabular}

low migration in comparison with $\mathrm{Zn}$ ions. Moreover, due to the small quantity of Ag ions in analysed samples, their concentration $\left(0.001 \mathrm{mg} \cdot \mathrm{dm}^{-2}\right)$ is close to the detection limit of equipment $\left(0.002 \mathrm{mg} \cdot \mathrm{L}^{-1}\right)$. The overall migration of $\mathrm{Zn}$ and $\mathrm{Cu}$ ions in acetic acid 3\% (w/v) (simulant $\mathrm{C}$ ) was higher than that occured in 10\% ethanol (simulant B) for all bionanocomposites. However, the overall migration for all samples is below than $10 \mathrm{mg} \cdot \mathrm{dm}^{-2}$ (the accepted value according to Regulation No 10/2011 [13]).

After the period of the migration test, no visual changes in the surface of films immersed in simulants were observed, and transparency was unaltered. Therefore based on the migration results it can conclude that the PLA-based bionanocomposites are suitable materials for the food packaging.

\subsection{Antibacterial activity}

Several studies have shown that the bacteria can adhere and form biofilm on different solid materials, such as metal, glass, rubber and plastic. Plastic materials are widely used in the food industry (e.g. as cutting surfaces, packages, tanks, pipes) and medical devices (prosthesis, catheters) where biofilms are undesirable since can cause serious problems such as introducing of continuous infections. Despite efforts to maintain the cleanliness of food packages, a very short contacting time is enough for bacteria to attach 
and form biofilms. Therefore, control of the bacterial adhesion plays an important role in maintaining the food quality [40]. In the adherence test, the initial adhesion was measured, which is the interaction between the cell surface and the material surface. The studied PLA-based films modified with $\mathrm{ZnO}: \mathrm{Cu} / \mathrm{Ag}$ nanoparticles were undergone to study their bacterial adherence inhibiting properties against $P$. aeruginosa which is a common Gram-negative bacterium and also against $S$. aureus gram positive bacterium commonly found in soil, water and surfaces of plants. The relative adhesion of different bacterial strains to neat PLA, plasticized PLA and PLA/ZnO:Cu/Ag nanocomposites is shown in Table 8 .

The adherence test revealed the high adherence of PLA against $S$. aureus and $P$. aeruginosa test organisms - Table 8 . This can be explained by residual lactic acid monomer in commercial PLA. Plasticized PLA showed a high inbibition on $S$. aureus.

The specimens with the highest concentration of $\mathrm{ZnO}: \mathrm{Cu} / \mathrm{Ag}$ NPs showed a better adherence against $S$. aureus, while inhibited the growth of $P$. aeruginosa. The better adhesion to $S$. aureus to polymeric composites is related to electrostatic affinity. Considering that $S$. aureus is a gram positive bacteria, it has more peptidoglycan than gram-negative bacteria because of their thicker cell walls. Thus, since the peptidoglycan is negatively charged and $\mathrm{Zn}$ and $\mathrm{Cu}$ ions are positively charged in the simulant media, the adherence of gram-positive bacteria is higher than in gram-negative bacteria [41].

Bacterial attachment to inert surfaces is a complicated process being influenced by the properties of both material surface characteristics and bacterial cell. Concerning the material surface characteristics it has been found that the irregularities of surfaces promote bacterial adhesion and biofilm deposition whereas the ultrasmooth surface does not favor bacterial adhesion and biofilm deposition. This may happen since a rough surface has a greater surface area and the depressions in the roughened surfaces provide

Table 8. The relative adhesion of different bacterial strains to neat PLA and PLA/ZnO:Cu/Ag samples

\begin{tabular}{|c|c|c|}
\hline Sample & $\begin{array}{c}\text { S. aureus } \\
{\left[\mathrm{CFU} / \mathrm{cm}^{2}\right]}\end{array}$ & $\begin{array}{l}\text { P. aeruginosa } \\
{\left[\mathrm{CFU} / \mathrm{cm}^{2}\right]}\end{array}$ \\
\hline PLA & $2.8 \pm 0.1 \cdot 10^{3}$ & $2.3 \pm 0.4 \cdot 10^{4}$ \\
\hline PLA/ZnO:Cu/Ag 0 & $1.0 \pm 0.2 \cdot 10^{3}$ & $1.9 \pm 0.2 \cdot 10^{4}$ \\
\hline PLA/ZnO:Cu/Ag 0.5 & $3.3 \pm 0.1 \cdot 10^{3}$ & $4.0 \pm 0.1 \cdot 10^{3}$ \\
\hline PLA/ZnO:Cu/Ag 1 & $6.5 \pm 0.1 \cdot 10^{3}$ & $6.3 \pm 0.1 \cdot 10^{2}$ \\
\hline PLA/ZnO:Cu/Ag 1.5 & $1.0 \pm 0.1 \cdot 10^{4}$ & $2.05 \pm 0.2 \cdot 10^{2}$ \\
\hline
\end{tabular}

more favorable sites for colonization. Also, bacteria adhere and colonize the porous surface preferentially. The important characteristics of bacteria which influence their adherence to a surface are the hydrophobicity and the surface charge [42]. The adhesion process of bacteria to the surfaces include interactions, such as van der Waals, Lewis acid-base, hydrophobic and electrostatic interactions [43]. However the molecular and physical interactions that govern bacterial adhesion to materials have not been understood in detail. Both specific and non-specific interactions may play an important role in the ability of the cell to attach to (or to resist detachment from) the material surface. It can conclude that the $\mathrm{ZnO}: \mathrm{Cu} /$ Ag NPs incorporation is suitable only for inhibition of the $P$. aeruginosa growth.

\section{Conclusions}

In this study, the effect of $\mathrm{Cu}$-doped $\mathrm{ZnO}$ powder functionalized with AgNPs on the structural, thermal, mechanical and antibacterial properties of the plasticized PLA was investigated.

The crystallinity degree increases with introduction of $\mathrm{ZnO}: \mathrm{Cu} / \mathrm{Ag}$ nanoparticles into plasticized PLA. The water vapor transmittance rate (WVTR) and oxygen transmitance rate (OTR) are improved for $\mathrm{PLA} / \mathrm{ZnO}: \mathrm{Cu} / \mathrm{Ag} 0.5$ in respect with neat PLA. At a high concentration of $\mathrm{ZnO}: \mathrm{Cu} / \mathrm{Ag}$ nanoparticles, their aggregation and non-homogeneous dispersion negatively affect these properties. The overall migration of all samples into three food simulants (distilled water - simulant A, ethanol 10\% (v/v) in aqueous solution - simulant B and acetic acid 3\% (w/v) in aqueous solution - simulant $C$ was below than $10 \mathrm{mg} \cdot \mathrm{dm}^{-2}$, accepted value according to EU Regulation No 10/2011 for plastic materials and articles intended to come into contact with food. Also, the PLA nanocomposites inhibited the growth of $P$. aeruginosa but they were not efficient as antimicrobial packaging against S. aureus.

Based on the obtained results it can conclude that the $\mathrm{PLA} / \mathrm{ZnO}: \mathrm{Cu} / \mathrm{Ag} 0.5$ bionanocomposite shows the best properties which offers suitable mechanical and thermal properties, good barrier properties to ultraviolet light, water vapour, oxygen and carbon dioxide, antibacterial activity and low migration of nanoparticles into food simulants. It can be appreciated that the new developed PLA/ZnO: $\mathrm{Cu} / \mathrm{Ag}$ bionanocomposites are promising materials for food packaging application. 


\section{Acknowledgements}

The research leading to these results has received funding from the Romanian ANCSI, Project ID P_40_404, under the Contract No 18/01.09.2016.

\section{References}

[1] Rhim J-W., Park H-M., Ha C-S.: Bio-nanocomposites for food packaging applications. Progress in Polymer Science, 38, 1629-1652 (2013).

https://doi.org/10.1016/j.progpolymsci.2013.05.008

[2] Huang J-W., Hung Y. C., Wen Y-L., Kang C-C., Yeh M-Y.: Polylactide/nano and microscale silica composite films. I. Preparation and characterization. Journal of Applied Polymer Science, 112, 1688-1694 (2009). https://doi.org/10.1002/app.29616

[3] Lagaron J. M., Lopez-Rubio A.: Nanotechnology for bioplastics: Opportunities, challenges and strategies. Trends in Food Science and Technology, 22, 611-617 (2011).

https://doi.org/10.1016/j.tifs.2011.01.007

[4] Sánchez Aldana D., Duarte Villa E., De Dios Hernández M., González Sánchez G., Rascón Cruz Q., Flores Gallardo S., Piñon Castillo H., Ballinas Casarrubias L.: Barrier properties of polylactic acid in cellulose based packages using montmorillonite as filler. Polymers, 6, 2386-2403 (2014). https://doi.org/10.3390/polym6092386

[5] Râpă M., Miteluţ A. C., Tănase E. E., Grosu E., Popescu P., Popa M. E., Rosnes J. T., Sivertsvik M., Darie-Niţă R. N., Vasile C.: Influence of chitosan on mechanical, thermal, barrier and antimicrobial properties of PLAbiocomposites for food packaging. Composites Part B: Engineering, 102, 112-121 (2016).

https://doi.org/10.1016/j.compositesb.2016.07.016

[6] Li Y., Han C., Bian J., Han L., Dong L., Gao G.: Rheology and biodegradation of polylactide/silica nanocomposites. Polymer Composites, 33, 1719-1727 (2012). https://doi.org/10.1002/pc.22306

[7] Sanchez-Garcia M. D., Lopez-Rubio A., Lagaron J. M.: Natural micro and nanobiocomposites with enhanced barrier properties and novel functionalities for food biopackaging applications. Trends in Food Science and Technology, 21, 528-536 (2010). https://doi.org/10.1016/j.tifs.2010.07.008

[8] Chen C-C., Chueh J-Y., Tseng H., Huang H-M., Lee S-Y.: Preparation and characterization of biodegradable PLA polymeric blends. Biomaterials, 24, 1167-1173 (2003). https://doi.org/10.1016/S0142-9612(02)00466-0

[9] Tri P. N., Domenek S., Guinault A., Sollogoub C.: Crystallization behavior of poly(lactide)/poly( $\beta$-hydroxybutyrate)/talc composites. Journal of Applied Polymer Science, 129, 3355-3365 (2013). https://doi.org/10.1002/app.39056

[10] Battegazzore D., Bocchini S., Frache A.: Crystallization kinetics of poly(lactic acid)-talc composites. Express Polymer Letters, 5, 849-858 (2011).

https://doi.org/10.3144/expresspolymlett.2011.84
[11] Armentano I., Fortunati E., Burgos N., Dominici F., Luzi F., Fiori S., Jiménez A., Yoon K., Ahn J., Kang S., Kenny J. M.: Processing and characterization of plasticized PLA/PHB blends for biodegradable multiphase systems. Express Polymer Letters, 9, 583-596 (2015). https://doi.org/10.3144/expresspolymlett.2015.55

[12] Arrieta M. P., López J., Hernández A., Rayón E.: Ternary PLA-PHB-Limonene blends intended for biodegradable food packaging applications. European Polymer Journal, 50, 255-270 (2014). https://doi.org/10.1016/j.eurpolymj.2013.11.009

[13] Union Guidelines on Regulation (EU) N 10/2011 On plastic materials and articles intended to come into contact with food. Official Journal of European Communities (2011).

[14] Vasile C.: Polymeric materials for food packaging. in 'New polymeric food packagings' (eds.: Vasile C., Cheaburu C. N). PIM, Iasi, 9-57 (2010).

[15] Silvestre C., Duraccio D., Cimmino S.: Food packaging based on polymer nanomaterials. Progress in Polymer Science, 36, 1766-1782 (2011).

https://doi.org/10.1016/j.progpolymsci.2011.02.003

[16] Espitia P. J. P., de Fátima Ferreira Soares N., dos Reis Coimbra J. S., de Andrade N. J., Cruz R. S., Medeiros E. A. A.: Zinc oxide nanoparticles: Synthesis, antimicrobial activity and food packaging applications. Food and Bioprocess Technology, 5, 1447-1464 (2012). https://doi.org/10.1007/s11947-012-0797-6

[17] Dhapte V., Gaikwad N., More P. V., Banerjee S., Dhapte V. V., Kadam S., Khanna P. K.: Transparent ZnO/polycarbonate nanocomposite for food packaging application. Nanocomposites, 1, 106-112 (2015). https://doi.org/10.1179/2055033215Y.0000000004

[18] Tankhiwale R., Bajpai S. K.: Preparation, characterization and antibacterial applications of $\mathrm{ZnO}$-nanoparticles coated polyethylene films for food packaging. Colloids and Surfaces B: Biointerfaces, 90, 16-20 (2012). https://doi.org/10.1016/j.colsurfb.2011.09.031

[19] Silvestre C., Duraccio D., Marra A., Strongone V., Cimmino S.: Development of antibacterial composite films based on isotactic polypropylene and coated $\mathrm{ZnO}$ particles for active food packaging. Coatings, 6, 4/1-4/14 (2016). https://doi.org/10.3390/coatings6010004

[20] Cushen M., Kerry J. P., Morris M., Cruz-Romero M., Cummins E.: Evaluation and simulation of silver and copper nanoparticle migration from polyethylene nanocomposites to food and an associated exposure assessment. Journal of Agricultural and Food Chemistry, 62, 1403-1411 (2014). https://doi.org/10.1021/jf404038y

[21] de Moura M. R., Mattoso L. H. C., Zucolotto V.: Development of cellulose-based bactericidal nanocomposites containing silver nanoparticles and their use as active food packaging. Journal of Food Engineering, 109, 520-524 (2012). https://doi.org/10.1016/j.jfoodeng.2011.10.030 
[22] Longano D., Ditaranto N., Cioffi N., Di Niso F., Sibillano T., Ancona A., Conte A., Del Nobile M. A., Sabbatini L., Torsi L.: Analytical characterization of laser-generated copper nanoparticles for antibacterial composite food packaging. Analytical and Bioanalytical Chemistry, 403, 1179-1186 (2012).

https://doi.org/10.1007/s00216-011-5689-5

[23] Ahmed J., Arfat Y. A., Castro-Aguirre E., Auras R.: Mechanical, structural and thermal properties of $\mathrm{Ag}-\mathrm{Cu}$ and $\mathrm{ZnO}$ reinforced polylactide nanocomposite films. International Journal of Biological Macromolecules, 86, 885-892 (2016).

https://doi.org/10.1016/j.ijbiomac.2016.02.034

[24] Ahmed J., Arfat Y. A., Castro-Aguirre E., Auras R.: Thermal properties of $\mathrm{ZnO}$ and bimetallic $\mathrm{Ag}-\mathrm{Cu}$ alloy reinforced poly(lactic acid) nanocomposite films. Journal of Thermal Analysis and Calorimetry, 125, 205-214 (2016). https://doi.org/10.1007/s10973-016-5402-1

[25] Brihi N., Bouaine A., Berbadj A., Schmerber G., Colis S., Dinia A.: No ferromagnetic properties in polycrystalline Al-doped $\mathrm{Zn}_{0.97} \mathrm{Mn}_{0.03} \mathrm{O}$ diluted magnetic semiconductor. Thin Solid Films, 518, 4549-4552 (2010). https://doi.org/10.1016/j.tsf.2009.12.028

[26] Vivekanandhan S., Schreiber M., Mason C., Mohanty A. K., Misra M.: Maple leaf (Acer sp.) extract mediated green process for the functionalization of $\mathrm{ZnO}$ powders with silver nanoparticles. Colloids and Surfaces B: Biointerfaces, 113, 169-175 (2014).

https://doi.org/10.1016/j.colsurfb.2013.08.033

[27] Auras R. A., Singh S. P., Singh J. J.: Evaluation of oriented poly(lactide) polymers vs. existing PET and oriented PS for fresh food service containers. Packaging Technology and Science, 18, 207-216 (2005). https://doi.org/10.1002/pts.692

[28] Lazar M. A., Vodnar D., Prodan D., Rotaru H., Roman C. R., Sorcoi L. A., Baciut G., Campian R. S.: Antibacterial coating on biocomposites for cranio-facial reconstruction. Clujul Medical, 89, 430-434 (2016). https://doi.org/10.15386/cjmed-599

[29] Dorigato A., Sebastiani M., Pegoretti A., Fambri L.: Effect of silica nanoparticles on the mechanical performances of poly(lactic acid). Journal of Polymers and the Environment, 20, 713-725 (2012).

https://doi.org/10.1007/s10924-012-0425-6

[30] Jayaramudu J., Das K., Sonakshi M., Reddy G. S. M., Aderibigbe B., Sadiku R., Ray S. S.: Structure and properties of highly toughened biodegradable polylactide/ZnO biocomposite films. International Journal of Biological Macromolecules, 64, 428-434 (2014). https://doi.org/10.1016/j.ijbiomac.2013.12.034

[31] Lim L-T., Auras R., Rubino M.: Processing technologies for poly(lactic acid). Progress in Polymer Science, 33, 820-852 (2008).

https://doi.org/10.1016/j.progpolymsci.2008.05.004

[32] Battegazzore D., Bocchini S., Frache A.: Crystallization kinetics of poly(lactic acid)-talc composites. Express Polymer Letters, 5, 849-858 (2011).

https://doi.org/10.3144/expresspolymlett.2011.84
[33] Darie-Niţă R. N., Vasile C., Irimia A., Lipşa R., Râpă M.: Evaluation of some eco-friendly plasticizers for PLA films processing. Journal of Applied Polymer Science, 133, 43223/1-43223/11 (2016).

https://doi.org/10.1002/app.43223

[34] Liu X., Wang T., Chow L. C., Yang M., Mitchell J. W.: Effects of inorganic fillers on the thermal and mechanical properties of poly(lactic acid). International Journal of Polymer Science, 2014, 827028/1-827028/8 (2014). https://doi.org/10.1155/2014/827028

[35] Wan X., Liang X., Zhang C., Li X., Liang W., Xu H., Lan S., Tie S.: Morphology controlled syntheses of $\mathrm{Cu}-$ doped $\mathrm{ZnO}$, tubular $\mathrm{Zn}(\mathrm{Cu}) \mathrm{O}$ and $\mathrm{Ag}$ decorated tubular $\mathrm{Zn}(\mathrm{Cu}) \mathrm{O}$ microcrystals for photocatalysis. Chemical Engineering Journal, 272, 58-68 (2015). https://doi.org/10.1016/j.cej.2015.02.089

[36] Klug H. P., Alexander L. E.: X-ray diffraction procedure for polycrystalline and amorphous materials. Wiley, New York (1974).

[37] Lu Y., Chen Y-C., Zhang P-H.: Preparation and characterisation of polylactic acid (PLA)/polycaprolactone (PCL) composite microfibre membranes. Fibres and Textiles in Eastern Europe, 24, 17-25 (2016). https://doi.org/10.5604/12303666.1196607

[38] Pascuta P., Vladescu A., Borodi G., Culea E., Tetean R.: Structural and magnetic properties of zinc ferrite incorporated in amorphous matrix. Ceramics International, 37, 3343-3349 (2011). https://doi.org/10.1016/j.ceramint.2011.05.134

[39] Reesha K. V., Panda S. K., Bindu J., Varghese T. O.: Development and characterization of an LDPE/chitosan composite antimicrobial film for chilled fish storage. International Journal of Biological Macromolecules, 79, 934-942 (2015). https://doi.org/10.1016/j.ijbiomac.2015.06.016

[40] Bayoumi M. A., Kamal R. M., Abd El Aal S. F., Awad E. I.: Assessment of a regulatory sanitization process in Egyptian dairy plants in regard to the adherence of some food-borne pathogens and their biofilms. International Journal of Food Microbiology, 158, 225-231 (2012). https://doi.org/10.1016/j.ijfoodmicro.2012.07.021

[41] Magyari K., Stefan R., Vodnar D. C., Vulpoi L.: The silver influence on the structure and antibacterial properties of the bioactive $10 \mathrm{~B}_{2} \mathrm{O}_{3}-30 \mathrm{Na}_{2} \mathrm{O}-60 \mathrm{P}_{2} \mathrm{O}_{2}$ glass. Journal of Non-Crystalline Solids, 402, 182-186 (2014). https://doi.org/10.1016/j.jnoncrysol.2014.05.033

[42] Katsikogianni M., Missirlis Y. F.: Concise review of mechanisms of bacterial adhesion to biomaterials and of techniques used in estimating bacteriamaterial interactions. European Cells and Materials, 8, 37-57 (2004). https://doi.org/10.22203/eCM.v008a05

[43] Faille C., Jullien C., Fontaine F., Bellon-Fontaine M-N., Slomianny C., Benezech T.: Adhesion of Bacillus spores and Escherichia coli cells to inert surfaces: Role of surface hydrophobicity. Canadian Journal of Microbiology, 48, 728-738 (2002). https://doi.org/10.1139/w02-063 